\title{
DIREITO À EDUCAÇÃO E POLÍTICA PÚBLICA DO PROUNI
}

RIGHT TO EDUCATION AND PUBLIC POLICY OF "PROUNI"

Maria Gorete Ferreira ${ }^{1}$ Elias Kallas Filho ${ }^{2}$

ISSUE DOI: $10.21207 / 1983.4225 .306$

\section{RESUMO}

O estudo discutiu a implementação de políticas públicas que asseguram o direito ao acesso no ensino superior, como meio de inserção na sociedade, buscando responder à seguinte questão: até que ponto o ProUni, como política pública contribui para o acesso ao ensino superior e a formação para a atuação profissional? Mediante o objetivo de conhecer os significados de ser estudante universitário beneficiado pelo ProUni, como política pública que pretende articular o efetivo exercício da igualdade. O trabalho desenvolveu-se em quatro capítulos. No primeiro, faz-se uma apresentação geral do direito à educação, fundamentado na CR e na LDB. No segundo, busca-se uma contextualização sobre o Programa, como política pública de ação afirmativa voltada à ampliação do acesso ao ensino superior. No terceiro, são demonstrados os resultados do estudo; no

\footnotetext{
${ }^{1}$ Possui graduação em Bacharelado pela Faculdade de Direito do Sul de Minas (2003). Mestra em Direito pelo Programa de Pós-graduação Stricto Sensu em Direito da Faculdade de Direito do Sul de Minas - FDSM (2013-2015). Professora de Processo Penal do Curso de Direito da Faculdade de São Lourenço (2015). Conhecimento amplo nos seguintes temas: Comitê de Ética em Pesquisa, iniciação científica e pesquisa.

2 Advogado. Docente da Faculdade de Direito do Sul de Minas - FDSM. Doutor em Direitocomercial pela USP. Pós-Doutor pela Fundação São Francisco de Assis-BH. Coordenador Científico e de Pós-Graduação da FDSM.
} 
quarto capítulo, tratou-se da discussão. O estudo foi de abordagem qualitativa, do tipo descritivo, de campo e transversal. Empregou-se o método do DSC. A amostra compôs por 30 alunos de ambos os gêneros, bolsistas ProUni, com idade entre 23 e 40 anos. A conclusão aponta para o fato de que o ProUni, contribuiu de maneira significativa para os bolsistas, que pertencem a população de baixa renda, possibilitando o efetivo exercício da igualdade.

Palavras-chave: Educação. Políticas Públicas. ProUni. Ensino Superior.

\section{ABSTRACT}

The study discussed the implementation of public policies that ensure the right of access to higher education as a means of integration into society, seeking to answer the following question: to what extent ProUni, as public policy contributes to access to higher education and training for professional practice? By the aim of knowing the meanings of being college student benefited by ProUni, as a public policy that articulates the effective exercise of equality. The work developed in four chapters. In the first, an overview is made of the right to education, based on the CR and LDB. In the second, we seek a contextualization of the program, as a public policy of affirmative action aimed at broadening access to higher education. In the third, they are shown the results of the study; in the fourth chapter, this was the discussion. The study was a qualitative approach, descriptive, field and cross. We used the DSC method. The sample was composed by 30 students of both genders, ProUni fellows, aged between 23 and 40 years. The finding points to the fact that ProUni, contributed significantly to the stock, which belong to the low income population, enabling the effective exercise of equality.

Keywords: Education. Public policy. ProUni. Higher education.

\section{INTRODUÇÃO}

O presente estudo tratará da implementação de políticas públicas que asseguram o direito ao acesso no ensino superior para a população de baixa renda como meio primordial para a inserção na sociedade, com a finalidade de um alcance da justiça social e pela busca de amplia- 
ção dos horizontes de cada cidadão, conforme previstos e assegurados na Constituição da República.

Diante disso, a pesquisa desenvolveu-se a partir dos seguintes objetivos: conhecer os significados de ser estudante universitário pelos bolsistas do Programa Universidade para Todos - ProUni, da Universidade do Vale do Sapucaí - Univás, Pouso Alegre, MG, como política pública que pretenda articular o efetivo exercício da igualdade.

O interesse pelo tema se deu em razão do contexto social e local dos alunos do ProUni da Univás, sobre o acesso à educação superior. Considera questões sociais como nível de pobreza, desigualdade social e condições raciais ${ }^{3}$; dificuldade de ingresso no mercado de trabalho, precariedade no ensino fundamental, dificuldades ao acesso no ensino médio ${ }^{4}$; discriminação, migrações entre as regiões do Brasil em busca de melhor qualidade de vida. Percebe-se que este cenário desestimula o ingresso ao ensino superior aos estudantes de camadas mais pobres da população, apesar das políticas públicas para geração de renda, que impactam na área de educação.

Portanto, observando-se todos esses aspectos no cotidiano acadêmico, sobretudo a informação de que o ProUni está cumprindo o seu papel social de facilitador na formação profissional, houve interesse em ouvir o discurso dos alunos participantes do referido programa que lhes garantiu o acesso ao ensino superior.

O presente estudo será de abordagem qualitativa, do tipo descritivo, de campo e transversal. A abordagem metodológica se deu na forma de pesquisa exploratória. Utilizou-se o método do Discurso do Sujeito

\footnotetext{
3 "Embora mais de $40 \%$ da juventude brasileira entre 18 e 24 anos, seja constituída por negros ou pardos, os que estão no ensino superior, nesta faixa etária, conforme já indicamos, são apenas $2 \%$ ". Neste contexto, com efeito, "o problema da desigualdade de oportunidades educacionais para pobres, negros e pardos frequentemente tende a se inscrever no âmbito da discussão acerca da elitização das universidades. SAMPAIO, Helena. A desigualdade no acesso ao ensino superior". Observações preliminares sobre os afrodescendentes. Acesso: http://nupps.usp.br/downloads/docs/dt0202.pdf.em 27 nov. 2013.

${ }^{4}$ Os alunos das camadas populares concluintes do ensino médio ainda sonham e anseiam pela universidade pública, o que lhes parece a melhor opção para graduar-se e, assim, buscar uma melhor oportunidade de trabalho no mercado cada vez mais competitivo. D'AVILA, G. T. O ensino superior como projeto profissional para "ser alguém": repercussões de um cursinho pré-vestibular popular na vida dos estudantes. Dissertação de Mestrado, Programa de Pós-Graduação em Psicologia, Universidade Federal de Santa Catarina, Florianópolis, SC. 2006.
} 
Coletivo (DSC), que se constituirá no método escolhido para a construção dos significadose nível de oportunidade, com o acesso ao ensino superior, permitindo uma maior aproximação com a casuística em estudo.

Os participantes do estudo serão 30 (trinta) alunos de ambos os gêneros, bolsistas ProUni da Univás, com idade entre 23 e 40 anos, que sejam beneficiários da bolsa ProUni.

Utilizou-se dois instrumentos: o primeiro questionário socioeconômico; o segundo foi uma entrevista semiestruturada, formado por quatro perguntas.

Por se tratar de pesquisa envolvendo seres humanos, foi submetido e aprovado pelo Comitê de Ética em Pesquisa - CEP da Universidade do Vale do Sapucaí de Pouso Alegre, MG, em 6/12/2013, sob o Parecer consubstanciado de $\mathrm{n}^{\circ}$ 482286, com o n. do CAAE 25401513.0.0000.5102.

\section{DIREITO FUNDAMENTAL SOCIAL À EDUCAÇÃO}

Neste capítulo expôs-se, sobre o direito fundamental social à educação, com ênfase na concretização do referido direito e as possíveis possibilidades de acesso aos níveis mais elevados de ensino. $\mathrm{O}$ direito à educação está incluso no rol dos direitos sociais fundamentais, recepcionado pela Constituição da República, com garantia de proteção prioritária. Como direito fundamental, a educação, ao lado da vida e da saúde, goza de prioridade de atendimento, principalmente em relação às crianças e adolescentes.

Atualmente, a essencialidade da educação básica é fundamental, para que o cidadão tenha condições mínimas de usufruir de uma vida digna, pois essa prerrogativa é oferecida a todos, com gratuidade e como dever estatal na ordem jurídica. Pois, sem esse requisito o indivíduo depara-se com grandes dificuldades para utilizar dos próprios serviços públicos oferecidos pelo próprio Estado. Para afirmar isso, Max Weber aponta que a burocracia existe em toda a sociedade, pois o crescimento e a complexidade das organizações, públicas ou não, passou a exigir modelos 
melhores, assim como ela se refere ao aumento de racionalização nos relacionamentos e nas crenças humanas. ${ }^{5}$

Outra condição permeada pela CR nesse aspecto é a Lei de Diretrizes e Bases da Educação Nacional - LDB (Lei n. 9.394/96) que oferece uma definição das bases da educação no país, definindo seus princípios e fins, sua estrutura organizacional, dos profissionais da educação e do sistema de recursos para a educação. ${ }^{6}$

Nessa dimensão, a LDB estabelece mecanismos e a estrutura educacional no Brasil. Representa um avanço marcante em relação às leis anteriores, especialmente no significado ampliado que atribui à educação. Dessa maneira, o direito à educação, consiste em direito público subjetivo, relacionado à cidadania e à dignidade da pessoahumana $(\mathrm{CR}$, art. 205); a educação assume no texto constitucional a característica fundamental de essência para o desenvolvimento da pessoa humana e do país. ${ }^{7}$

\subsection{O DIREITO À EDUCAÇÃO NA CONSTITUIÇÃO DA REPÚBLICA}

A educação no Brasil teve sua estrutura formalizada e normatizada a partir da Constituição da República Federativa do Brasil de 1988 (CR) e na Lei de Diretrizes e Bases Nacional de $1996^{8}$, além de uma série de decretos oficiais e resoluções do Conselho Nacional de Educação. A $\mathrm{CR}$ assegura o direito à educação ao defini-lo como dever do Estado no artigo 205: "a educação, direito de todos e dever do Estado e da família,

\footnotetext{
${ }^{5}$ WEBER, Max. Economia e Sociedade. São Paulo: Imprensa Oficial do Estado de São Paulo, 1999.

${ }^{6}$ PORTO, Claudio; RÉGNIER, Karla. O Ensino Superior no Mundo e no Brasil Condicionantes Tendências e Cenários para o Horizonte 2003-2025: Uma Abordagem Exploratória. Dezembro, 2003. Disponível em: http://portal.mec.gov.br/sesu/arquivos/pdf/ensinosuperiormundobrasiltendenciascenarios2 003-2025.pdf. Acesso em 29 de jan de 2014.

${ }^{7}$ MARQUES, Antonio Emílio Sendimet al. Pela Justiça na Educação. 2000.

${ }^{8}$ A Lei de Diretrizes e Bases da Educação Brasileira (LDB nº. 9394/96) é a legislação que regulamenta o sistema educacional (público ou privado) do Brasil (da educação básica ao ensino superior). Reafirma o direito à educação, garantido pela Constituição da República e divide a educação brasileira em dois níveis: a educação básica e o ensino superior. Disponível em: <portal.mec.gov.br/arquivos/pdf/ldb.pdf. >. Acesso em 12 nov 2013.
} 
será promovida e incentivada com a colaboração da sociedade, visando ao pleno desenvolvimento da pessoa, seu preparo para o exercício da cidadania e sua qualificação para o trabalho".

A interpretação do art. 205 deixa explícito que a sociedade deverá ter uma visão mais ampla para a educação ${ }^{9}$, que representa um processo integral de formação humana, não devendo limitar-se ao conceito menor de que educar é transmitir conhecimento a serem armazenados no intelecto.

Nesse aspecto, ao definir como dever do Estado a educação (artigo 205) e o seu compromisso com o desenvolvimento nacional e com a construção de uma sociedade livre, justa e solidária (artigo $3^{\circ}$ ), a CR possibilita a individualização da educação superior como bem jurídico, dado o seu papel na formação de recursos humanos nas áreas da ciência, pesquisa e tecnologia (artigo $218, \S 3^{\circ}$ ), e no desenvolvimento do País ${ }^{10}$.

Dessa forma, pode-se dizer que o objetivo da Constituição da República, no que tange aos direitos sociais, pode ser resumido na promoção do bem-estar do homem, cujo ponto de partida está em assegurar as condições de sua dignidade, que inclui, além da proteção dos direitos individuais, condições materiais mínimas de existência. Ao apurar os elementos fundamentais dessa dignidade (o mínimo existencial) ${ }^{11}$, estarse-ão estabelecendo exatamente os alvos prioritários dos gastos públicos.

O Estado precisa antes de tudo compreender a educação como investimento e não como despesa, precisa utilizar seu aparato oficial e instituições para promover o ensino sob todas as formas, principalmente, conforme aquelas explicitadas, no artigo 208, V, “acesso aos níveis mais

\footnotetext{
9 Importante distinção entre os termos "educação" e "ensino" não se confundem. O "ensino" constitui a principal forma de se realizar a "educação", entendida esta como a educação escolar. A LDB traz em seu artigo $1^{\circ}$, que a educação escolar é aquela desenvolvida, predominantemente, por meio do ensino, em instituições próprias. Disponível em: <portal.mec.gov.br/arquivos/pdf/ldb.pdf. >. Acesso em 12 nov 2013.

${ }^{10}$ RANIERI, N.B.S. (2000). Educação superior, direito e Estado na Lei de Diretrizes e Bases (Lei n. 9.394/96). São Paulo: EDUSP /Editora da Universidade de São Paulo.

${ }^{11}$ A noção de mínimo existencial encontra raízes no direito alemão. Como a Constituição alemã não possui um rol extenso de direitos sociais, os constitucionalistas, ao lado do Tribunal Constitucional alemão, debruçaram-se na construção de qual seria o conteúdo mínimo a ser assegurado pelo Estado alemão aos seus cidadãos, afirmando existir "ao menos um direito fundamental social não-escrito", ao sustentar "a existência de um direito subjetivo ao mínimo existencial”. ALEXY, Robert. Teoria dos Direitos Fundamentais. Tradução de Virgilio Afonso da Silva. São Paulo: Malheiros Editores, 2008, p. 437.
} 
elevados do ensino, da pesquisa e da criação artística, segundo a capacidade de cada um", da Constituição da República.

\subsection{A EDUCAÇÃO SUPERIOR COMO DIREITO NO ÂMBITO CONSTITUCIONAL}

A educação superior tornou-se, de maneira indiscutível, uma possibilidade de conhecimento oferecido à população que se encontra na faixa etária de 18 a 24 anos, sendo vista como um implemento na busca e concretização da cidadania. Para garantir o gozo desse direito, é importante conhecer o conteúdo instrumental colocado à disposição da população de baixa renda, para viabilizar a proteção ou o resgate do direito, concretizado pelas políticas públicas. Primeiramente, relata-se que Constituição da República, dispõe de uma base garantista do direito fundamental à educação. ${ }^{12}$

No entanto, ao falar sobre formas de regulação e gestão da educação superior no Brasil, é relevante destacar os princípios norteadores da educação, que são oriundos da $\mathrm{LDB}$, nos artigos $2^{\circ} \mathrm{d} 3^{\circ}$, que é referência básica para a educação nacional, com vários dispositivos sobre a educação superior e diversos instrumentos e mecanismos que preconizam a reforma desse nível de ensino e de sua relação orgânica com o processo de reforma do Estado.

Esse projeto de reforma é o que institui o Programa Universidade para Todos (ProUni), por intermédio da Lei Federal n. 11.096/2005, que trata da concessão de bolsas de estudos nas modalidades integral e parcial a estudantes carentes, em cursos de graduação e sequenciais de formação específica, em instituições privadas de ensino superior. E tem por objetivo contribuir para ampliar o acesso à educação superior daqueles que, pelas vias regulares, dificilmente teriam acesso a essa formação.

Neste sentido, o ProUni constitui iniciativa, ainda que tímida, de redistribuição indireta de renda, uma vez que o governo oferece às IES

12 PORTO, Claudio; RÉGNIER, Karla. O Ensino Superior no Mundo e no Brasil Condicionantes, Tendências e Cenários para o Horizonte 2003-2025: Uma Abordagem Exploratória. Dezembro, 2003. Disponível em: http://portal.mec.gov.br/sesu/arquivos/pdf/ensinosuperiormundobrasiltendenciascenarios2 003-2025.pdf. Acesso em 29 de jan de 2014. 
privadas, que aderem ao programa uma contrapartida de transferência de recursos de isenção fiscal a estratos populacionais mais pobres, já que tais recursos, caso fossem arrecadados, certamente não beneficiariam necessariamente esses grupos sociais.

Para isto, trazem-se fundamentos sustentados por Schwarztman, que evidencia nesse sentido que "as profundas diferenças sociais que existem no Brasil justificam a adoção de políticas de inclusão social que estimulem o interesse e o acesso ao ensino superior de pessoas, grupos, setores sociais e habitantesde regiões aonde o ensino superior é menos acessível". ${ }^{13}$ Dessa maneira, faz-se necessário apontar dimensões sobre o papel do Estado e do Direito visando uma concretização do direito fundamental social à educação, conforme explicitado no próximo item.

\subsection{O PAPEL DO ESTADO E DO DIREITO NA CONCRETIZAÇÃO DO DIREITO FUNDAMENTAL SOCIAL À EDỦCAÇÃO}

A Constituição da República expõe no artigo $1^{\circ}$ os fundamentos base da República Federativa do Brasil, com a finalidade de constituir-se a Nação em Estado Democrático de Direito. A partir daí, busca-se entender os desafios, enfrentados pela sociedade contemporânea, tendo uma visualização especialmente, no que tange à "cidadania". Dessa maneira, olhando para a construção do Constitucionalismo no Brasil, verificou-se a experimentação de sete constituições no Brasil, no período de 1824 a 1988, incluindo a atual. No entanto, em 5 de outubro de 2015, completouse 27 anos da promulgação da Constituição da República, a conhecida "Constituição Cidadã".

Considerando que o neoconstitucinalismo é um fenômeno pósguerra, que foi afeiçoado por inúmeras transformações sociais, porém ingressou-se tardiamente no Brasil, ou seja, no ambiente constitucional. Talvez seja por isso, que ainda não alavancou a tutela que está relacionada com a proteção dos direitos fundamentais. Ou ainda, com as chamadas promessas da modernidade.

13 SCHWARTZMAN, S. Por uma nova política de educação superior para o Brasil. 2007. Disponível em: http://www.schwartzman.org.br/sitesimon/?page_id=595\&lang=ptbr. Acesso em 15 de mar de 2014. 
As políticas sociais estão atreladas ao contexto da sociedade moderna capitalista. Nesse sentido, por exemplo, a efetivação de uma política pública voltada à inclusão social no ensino superior busca a garantia do acesso, a equidade de oportunidades e a efetivação da democratização do meio social. Isto para que o cidadão possa ter condições socioeconômicas compatíveis com aquelas que são impostas pela sociedade, que requer qualificações e conhecimento para a integração da ordem liberal e capitalista do momento.

O novo paradigma insculpido pelo Estado Democrático de Direito, surge trazendo um novo constitucionalismo do pós-guerra que preceitua uma "essência", ou seja, que acrescenta um "mais" ao Direito, prescrito no próprio texto constitucional. Essa especificidade sob o processo de revitalização do jurídico recebe o nome de "plusnormativo". ${ }^{14}$ Assim possibilitando uma perspectiva auxiliar no processo de transformação da realidade, buscando permear as realidades jurídico-políticas junto à jurisdição constitucional, queno Estado Democrático de Direito, vai se transformar no garantidor dos direitos fundamentais-sociais e da própria democracia, que é um permanente processo de construção, diante das complexidades sociais. ${ }^{15}$

Ademais, visando alavancar a força do Direito por meio do plus normativo, o Estado Democrático de Direito, busca uma forma de valorização do jurídico sob as perspectivas e possibilidades de concretização dos direitos fundamentais. Isto é direcionável para o acesso à administração do futuro ao entrelace do constitucionalismo moderno. Para além de conseguir o alcance do plus normativo, vislumbra-se que a Constituição compromissária fica estagnada num sentido negativo, uma vez que, não apresenta os resultados propostos segundo a "essência" acrescida ao Direito. ${ }^{16}$

${ }^{14}$ SCHWARTZMAN, S. Por uma nova política de educação superior para o Brasil. 2007. Disponível em: http://www.schwartzman.org.br/sitesimon/?page_id=595\&lang=ptbr. Acesso em 15 de mar de 2014.

15 STRECK, Lênio Luiz. Hermenêutica, Neoconstitucionalismo e o "problema da discricionariedade dos juízes". Disponível em: <http://www.opet.com.br/revista/direito/primeira_edicao/artigo_Lênio_Luiz_Streck_ hermene.utica.pdf> Acesso em 8.5.2014

16 STRECK, Lênio Luiz. Jurisdição Constitucional e Hermenêutica: Perspectivas e Possibilidades de Concretização dos Direitos Fundamentais Sociais no Brasil. Novos Estudos Jurídicos, vol. 8, n. 2, maio/ago. 2003, p. 257-301. 
Para isso, o Estado Democrático de Direito buscou diante da condição situacional, que estava para a realização dos direitos fundamentais sociais uma condição denominada de "realização das promessas da modernidade". Portanto, resgatar as promessas da modernidade é tarefa bastante árdua, no que tange a concretização de direitos fundamentais e sociais, garantidos na Constituição, quando se fala em pleno exercício da igualdade, acesso à justiça social e participação democrática. ${ }^{17}$

No entanto, o resgate das promessas da modernidade visa um desenvolvimento, ou seja, a possibilidades de concretização, no que tange ao núcleo específico de direitos fundamentais-sociais. Nesse sentido, quando o Direito busca cumprir a materialidade do texto constitucional, por meio do instrumento de implementação de políticas públicas é necessário que utilize do plus normativo, para que haja um alcance da justiça social e um equilíbrio frente aos caminhos traçados pelo capitalismo. ${ }^{18}$

Em razão do exposto, cumpre salientar que a ideia de Constituição que se pretende é aquela que contenha uma força normativa capaz de assegurar o núcleo de direitos à modernidade tardia não cumprida. Desse modo, a força normativa da Constituição não pode optar pela concretização de dispositivos menos ou mais significativos, no âmbito do núcleo essencial-fundamental. Com isso, a legitimidade do texto constitucional aponta com firmeza e determinação, uma essência da Constituição sob os direitos sociais fundamentais, porém, há uma ambiguidade para a perspectiva e possibilidade de realização de tais direitos. ${ }^{19}$

Por outro lado, na Constituição o direito subjetivo à educação básica, com acesso gratuito e garantido, somente este nível de ensino não é suficiente para possibilitar ao cidadão perspectivas e realizações nos seus direitos, frente à realidade brasileira. Dessa maneira, pode-se dizer que o plusnormativo foi aferido à política pública, por meio da instituição da Lei $n^{\circ}$. 11.096/2005, que vislumbra o acesso ao ensino superior.

${ }^{17}$ STRECK, Lênio Luiz. Jurisdição Constitucional e Hermenêutica: Perspectivas e Possibilidades de Concretização dos Direitos Fundamentais Sociais no Brasil. Novos Estudos Jurídicos, vol. 8, n. 2, maio/ago. 2003, p. 257-301.

${ }^{18}$ Ibidem, p. 277.

${ }^{19}$ Ibidem, p. 280. 


\subsection{LIBERDADE, IGUALDADE, CIDADANIA E DEMOCRACIA COMO PRESSUPOSTOS PARA A CONCRETIZAÇÃO DE UM DIREITO}

Em referência ao que tange, a concretização de um direito, é preciso pontuar alguns elementos fundamentais, que se encontram inclusos na Constituição da República, para que seja possível tal efetivação. Sob essa objeção, de início, é primordial que seja considerado, essencialmente, que o indivíduo esteja assegurado de sua liberdade, visando à busca da cidadania, ainda com finalidade de uma igualdade, que seja viável como base de uma autoorganização dos indivíduos interessados em uma justiça social, pautados num caráter realizador de direito, onde se depara com uma condição fundamental e universal que é a democracia, vista como uma renovação progressiva da sociedade.

Em razão do exposto acima, menciona-se a superioridade jurídica da Constituição, que tem por finalidade instituir um Estado Democrático de Direito, queexpõe como um de seus fundamentos a cidadania e busca direcionar as formas/ações pelas quais as relações sociais podem ser reguladas e construídas regras civilizadas de sociabilidade. Além disso, a superioridade da Constituição se configura pelos princípios universalistas da liberdade e igualdade, campo no qual surgem os sujeitos sociais (cidadãos) que buscam implementar um projeto de construção democrática e transformação social.

Primeiramente salienta-se sobre a liberdade, no que tange ao arbítrio do indivíduo em expor seus ideais, com base no preâmbulo da Constituição da República, que institui um Estado Democrático de Direito, com fins assegurados na liberdade para o exercício dos direitos sociais e individuais. E ainda, pautando a liberdade como um atributo natural de todos os seres humanos, sem qualquer exceção, e deve ser protegida por toda a sociedade, como direito inerente à condição humana.

Em razão do exposto acima é possível verificar a relevância em utilizar o método do DSC, e possibilitar a liberdade do sujeito pesquisado, ou seja, do beneficiado pela política pública, quando se deu oportunidade para o indivíduo "falar/expressar-se" sobre a experiência em ter acesso ao ensino superior, e após esse momento obter como resultado o efeito de tal procedimento, aproximando-o do direito à liberdade.

A cidadania é identificada na presente pesquisa, quando o indivíduo se manifesta interesse (liberdade) em usufruir da política pública 
que possibilita o acesso ao ensino superior, assim permitindo que tenha condições de transformar-se em um cidadão capaz de mudar a sua situação social, "de classe baixa", passando a integrar na sociedade como um cidadão de "classe média", com possibilidades de acesso a outros direitos. Também a cidadania se manifestou no momento que ele teve a liberdade de expor suas ideias, em relação ao benefício da política pública do ProUni.

Ainda com vistas ao exposto, referente à liberdade, à igualdade e cidadania, o entendimento de tais fundamentais busca um ideal de concretização de um direito, por meio do efetivo exercício da cidadania, para afirmar isso, cita-se Ihering: "o direito é um trabalho sem tréguas, não só do Poder Público, mas de toda a população". ${ }^{20}$

Por outro lado, quando se fala em concretização de um direito, tendo em vista a complexidade em torno dos fundamentos já discutidos acima, vislumbra-se a necessidade de um mecanismo para mediar o acesso e assegurar a garantia a todos os indivíduos quanto aos seus direitos fundamentais. Para isso, surge com uma característica singular exatamente a disputa em torno das dimensões que definem a cidadania, estabelecendo uma dinâmica democrática com possibilidades de participação de toda a sociedade.

A partir disso, manifesta-se a relevância em estabelecer uma definição sobre democracia, referindo aos elementos já explicitados que circundam o contexto. Em decorrênciatraz-se à tona o enunciado constitucional que diz "Todo o poder emana do povo, que o exerce por meio de representantes eleitos ou diretamente, nos termos desta Constituição". Por isso, a Constituição de 1988 pode ser considerada não apenas o marco da re-democratização brasileira, mas também a instituição das bases normativas de um regime político no qual a população é amplamente conclamada a ter um papel ativo, para assegurar por meio do regime democrático, o exercício dos direitos de cidadania em uma sociedade reconhecidamente marcada por fortes e históricas desigualdades sociais. ${ }^{21}$

\footnotetext{
${ }^{20}$ IHERING, Rudolf von. A luta pelo direito. Trad. Pietro Nassetti. São Paulo: Martin Claret, 2003, p. 27.

${ }^{21}$ RIBEIRO, Luiz César de Queiroz; SANTOS JUNIOR, Orlando Alves dos. "Democracia e cidade: divisão social da cidade e cidadania na sociedade brasileira", Análise Social, volume XL (174). p 88.
} 
Para que haja a concretização de um direito, deve-se levarem conta a realidade histórica juntamente com as desigualdades sociais devido a isso tem que lembrar que o Estado Democrático de Direito, propunha transformações que seriam atingidas por meio da democracia sob a forma de "promessas não cumpridas", "ou de contraste entre a democracia ideal tal como concebida por seus pais fundadores e a democracia real em que, com maior ou menor participação, devemos viver cotidianamente". ${ }^{22}$ Isto tudo sendo mediado por um delicado equilíbrio entre liberdade e justiça social.

No entanto, mesmo havendo uma expressão baixa de capacidade participativa, pela reduzida taxa de demandas, pelo descrédito na eficácia do Estado há uma condição fundamental para a efetividade da democracia, que vem associada não apenas à existência dos direitos formais, mas às possibilidades de inclusão social dos indivíduos no conjunto de laços, valores, normas, que expressam a aposta da sociedade na vida democrática. Ou seja, às condições necessárias ao exercício da cidadania dotada de razão, integridade física e capaz de tomar decisões em termos dos seus reais interesses. Assim será objeto do próximo capítulo a exposição sobre políticas públicas, sendo vistas como uma condição a garantia de acesso à educação superior.

\section{$2 \quad$ POLÍTICAS PÚBLICAS E O PROUNI}

Políticas públicas figuram neste trabalho como um dos elementos principais, para a estrutura e desenvolvimento do contexto que será o foco da pesquisa, mais precisamente sendo, políticas públicas de inclusão, especialmente, aquelas de ação afirmativa, que buscam a efetivação dos direitos subjetivos, por meio do acesso ao ensino superior. Privilegiamos a política pública de inclusão a estabelecida pelo surgimento da Lei $\mathrm{n}$. 11.096/2005, que institui o ProUni.

Nesse contexto, discutir o acesso ao ensino superior por meio das políticas públicas educacionais requer uma análise pormenorizada do campo teórico e da própria da política pública, que o implementa. Isto porque se verifica que o processo educativoestá situado geográfica e his-

\footnotetext{
22 BOBBIO, Norberto; NOGUEIRA, Marco Aurélio. O futuro da democracia: uma defesa das regras do jogo. Rio de Janeiro: Paz e Terra, 1997.
} 
toricamente, o que significa que se realiza deformatos diferentes em cada espaço social e em cada espaço de tempo. Sob estaótica, se faz necessário, primeiramente, esclarecer o significado da expressão políticas públicas.

Para que haja fundamentos para uma implementação de política pública, devem coexistir características que sejam expressão pura e genuína do interesse geral da sociedade, o que implicam a ocorrência de interrelação entre papeis políticos e administrativos. Assim para a formulação de políticas públicas, segundo as funções primordiais que sustentam o eixo estatal/administrativo, há que se levar em conta três seguimentos: o planejamento, o orçamento e a execução.

\subsection{POLÍTICAS PÚBLICAS NA CONSTITUIÇÃO DA REPÚBLICA PARA EFETIVIDADE DO DIREITO À EDUCAÇÃO}

As políticas públicas surgem no ordenamento jurídico, como instrumento regulamentador do conteúdo essencial dos direitos sociais para a consecução de estratégica de finalidades políticas e econômicas principalmente, com intuito de realçar e garantir a efetividade daquele direito que está implícito no texto constitucional.

De outro lado, têm-se as demandas sociais do Estado, que emergem da sociedade e do seu próprio interior. Com isso, as políticas públicas ganham relevo como sinônimo de compromisso público de atuação numa determinada área, assim com vistas ao atendimento à questão social, sendo para tal cumprimento em longo prazo. ${ }^{23}$

\footnotetext{
${ }^{23}$ Para confirmar essa acepção, Carvalho salienta que "as respostas políticas dos diversos países à questão social, embora diferenciadas, apresentam algumas medidas comuns, entre elas: o corte de benefícios ou a introdução de medidas de flexibilização do acesso a elas; a maior seletividade e a focalização das política sociais, tornando-as residuais e causais, ou seja, os programas não são contínuos nem abrangentes e atingem pequenos grupos por determinado tempo; a privatização de programas de bem estar social, isentando o estado da garantia dos mínimos sociais necessários à sobrevivência humana; e o desmonte da rede de proteção social antes mantida pelo Estado.CUNHA, Edite da Penha; CUNHA, Eleonora Schettini M. Política públicas sociais. In: CARVALHO, Alysson ...[et al.] organizadores. Políticas Públicas. Belo Horizonte: Editora UFMG; Proex, 2002, p. 12-13.
} 
A Constituição da República definiu uma nova forma à organização do sistema federativo brasileiro, reconhecendo o direito à proteção social devido pelo Estado como universal (extensivo a todo cidadão). A partir disso, reorganizou-se o papel do governo federal, pois esse novo formato baseava-se num tripé estrutural, estabelecidos como entes federativos autônomos, sendo estes responsáveis pela execução das políticas sociais, nos limites cabíveis dentro da esfera federal, estadual e municipal. $^{24}$

Com isso, visando atender às demandas sociais, o Estado para dar efetividade aos direitos sociais inscritos na Constituição da República, age por meio de implementação de políticas públicas que concretizem os direitos conquistados, porém, com restrições políticas e econômicas impostas para a sua implementação. ${ }^{25}$

Em observações às diretrizes constitucionais, necessita-se de cuidados especiais, quanto ao controle positivado na ordem constitucional, sobre a tripartição das funções do Estado, cada uma com atribuições típicas e atípicas. Para isso, Aguiar ressalta que as funções atípicas seriam aquelas que formam "uma sintonia entre as funções do Estado, que não obstante independentes e harmônicos, se entrelaçam, se controlam e agem em conjunto visando à finalidade do Estado, a harmonia da vida em sociedade com dignidade". 26

Diante desse contexto da separação de funções, para aclamar o tema específico do presente trabalho, destaca-se que cabe ao Poder Legislativo a atribuição da produção normativa, a edição das leis, respeitando os procedimentos legais para a realização do processo legislativo. E por outro lado, cabe ao Poder Executivo a função de administrar, de gerir o estado, de implementar as políticas públicas, isto é, colocar a máquina administrativa em movimento contínuo e progressivo, visando atender aos anseios da sociedade, nos mais diversos aspectos e pugnando sempre pelo controle social. ${ }^{27}$

\footnotetext{
${ }^{24}$ CUNHA, Edite da Penha; CUNHA, Eleonora Schettini M. Política públicas sociais. In: CARVALHO, Alysson ...[et al.] organizadores. Políticas Públicas. Belo Horizonte: Editora UFMG; Proex, 2002, p. 14-15.

25 Ibidem, p. 17.

${ }^{26}$ Ibidem, p. 16.

${ }^{27}$ AGUIAR, Eduardo Henrique de Almeida. Jurisdicionalização de Políticas Públicas. Ed. Rio de Janeiro: Livre Expressão, 2010, p. 18.
} 
Dessa maneira, percebe-se que a função típica de implementar políticas públicas é atribuída ao executivo, sendo que este deve para tanto, avaliar a área que carece de implementações políticas, definir prioridades dentre as diversas questões sociais de maior relevância, preparar a proposta orçamentária, fazer constar da próxima proposta orçamentária a verba necessária à implementação da política, orientando os investimentos estatais na concretização das políticas públicas, pois as leis orçamentárias serão discutidas e votadas pelo Legislativo, que assim detém o controle finalístico dos gastos públicos. ${ }^{28}$

Nesse sentido, para confirmar tal posição Elias Kallás Filho esclarece que:

As políticas públicas, embora também muito ligadas à ordenação da atividade econômica e à satisfação de necessidades sociais, parecem integrar mais apropriadamente essa função de direcionamento do processo econômico, uma vez que visam orientar a atuação conjunta dos vários setores do Estado na busca de objetivos de médio e longo prazo, com destacado objetivo de modificação da realidade através do direito e da política. Com efeito, elementos importantes da constituição econômica somente podem ser efetivados por meio de políticas públicas, não se satisfazendo com a mera produção legislativa ou com a criação de um órgão da Administração Pública. ${ }^{29}$

Observando essa situação, faz-se necessário para uma iniciativa de formular e executar uma política pública, que haja uma integração da gestão social e sociedade civil. Isto com vistas à qualidade dos serviços prestados, a responsabilidade do órgão de gestão pelo exercício das funções de planejamento, monitoramento e avaliação dos resultados que

${ }^{28}$ AGUIAR, Eduardo Henrique de Almeida. Jurisdicionalização de Políticas Públicas. Ed. Rio de Janeiro: Livre Expressão, 2010, p. 19.

${ }^{29}$ KALLÁS FILHO, Elias. A Constituição Econômica de 1988: Fundamentos, funções e enunciados - síntese. In: Democracia e Constitucionalismo/Alexandre Gustavo Melo Franco Bahia...[et al.]; coordenadores Eduardo Henrique Lopes Figueiredo ...[et al.]. - Rio de Janeiro: Elsevier, 2012, p. 135. 
serão alcançados pelas ações e o possível impacto das políticas na melhoria da qualidade de vida dos beneficiados.

Enfim, a expressão "políticas públicas" sendo parte acessória fundamental para o desenvolvimento do objeto principal desse estudo, requer uma delimitação maior de seu conceito, e para isso busca-se uma definição em Frischeisen que expõe ser "o conjunto de ações que o Poder Público realiza, visando o efetivo exercício da igualdade, base de toda a ordem social" 30 , fundada no Estado Democrático de Direito.

\subsection{A OPERACIONALIZAÇÃO DE UMA POLÍTICA PÚBLICA PARA O DESENVOLVIMENTO}

As políticas públicas são traçados com base nos objetivos fundamentais da República Federativa do Brasil, que se encontram pautados no artigo $3^{\circ}$ da Constituição da República. Assim, é relevante entender a divisão constitucional de competências legislativas e administrativas entre os entes da federação, que são incumbências do Estado. Isto para que haja conhecimento sobre a organização estatal, autonomia administrativa e normativa, quando se fala em responsabilidade do ente da federação, no que se refere à implementação de determinada política pública. ${ }^{31}$

Com isso, observa-se que a operacionalidade de uma política pública possibilita que o Estado, partindo de sua atuação norteará os fins previstos na norma constitucional, especialmente, àqueles explicitados pelo legislador nos objetivos fundamentais da República Federativa do Brasil. Para complementar tal entendimento, assenta no contexto quando o Estado pugna por "garantir o desenvolvimento nacional".

Ainda com intuito de esclarecer o sentido da expressão desenvolvimentoé relevante pontuar a característica de um desenvolvimento para um país. Para realçar essa posição quanto ao desenvolvimento, Heidemann expõe que "desenvolver um país significava, e ainda significa, basicamente, implantar uma economia de mercado que inclua, se não a totalidade, pelo menos a maior parte de seus cidadãos".

${ }^{30}$ FRISCHEISEN, Luiza Cristina Fonseca. Políticas Públicas a responsabilidade do administrador e o ministério público. São Paulo: Ed. Max Limonand. 2000, p. 57.

31 AGUIAR, Eduardo Henrique de Almeida. Jurisdicionalização de Políticas Públicas. Ed. Rio de Janeiro: Livre Expressão, 2010, p. 32-33. 
Com vistas a finalizar o entendimento sobre a operacionalização de políticas públicas, tratando-se de aspectos políticos-administrativos, compreende-se que o "desenvolvimento de uma sociedade resulta de decisões formuladas e implementadas pelos governos dos Estados nacionais, subnacionais e supranacionais em conjunto com as demais forças vivas da sociedade, sobretudo as forças do mercado em seu sentido lato. Em seu conjunto, essas decisões e ações de governo e de outros atores sociais constituem o que se conhece com o nome genérico de políticas públicas". 32

\subsection{POLÍTICAS PÚBLICAS DA EDUCAÇÃO SUPERIOR NO BRASIL}

As políticas públicas voltadas à educação superior, no contexto brasileiro surge de modo a atender as interdisciplinaridades. Assim respeitando o estatuto de cada ciência, a análise interdisciplinar busca gerar um pensamento renovado e abrangente, que se situa no âmbito das Ciências Jurídicas, da Ciência Política e da Ciência da Educação.

Para melhor compreensão do exposto, Ivani Fazenda relata sobre isso que "a interdisciplinaridade leva todo especialista a reconhecer os limites do seu saber para acolher as contribuições das outras disciplinas. Assim sendo, uma ciência e complemento de outra, e a dissociação, a separação entre as ciências é substituída pela convergência a objetivos comuns". 33

Com base na concepção acima, há um esforço em definir políticas públicas, para isso apoia-se no entendimento de Fábio Konder Comparato, "as políticas públicas são programas de ação governamental "34. O

\footnotetext{
${ }^{32}$ HEIDEMANN, Francisco G. SALM, José Francisco/organizadores. Políticas Públicas e desenvolvimento. Brasília: Editora Universidade de Brasileira, $2^{\circ}$ edição, 2010, p. 28.

${ }^{33}$ FAZENDA, Ivani. Interdisciplinaridade: qual o sentido? São Paulo: Paulus, 2003. (Questões Fundamentais da Educação). p. 43.

${ }^{34}$ Para Comparato o conceito de política, no sentido de programa de ação, só recentemente passou a fazer parte das cogitações da teoria jurídica. E a razão é simples: ele corresponde a uma realidade inexistente ou desimportante antes da Revolução Industrial, durante todo o longo período histórico em que se forjou o conjunto dos conceitos jurídicos dos quais nos servimos habitualmente. COMPARATO, Fábio Konder. Ensaio sobre o juízo de constitucionalidade de políticas públicas. Revista dos Tribunais, n. 737, março, São Paulo, 1997, p. 17).
} 
autor segue a posição doutrinária de Ronald Dworkin, para quem a política (policy), contraposta à noção de princípio, designa aquela espécie de padrão de conduta (standard) que assinala uma meta a alcançar, no mais das vezes uma melhoria das condições econômicas, políticas ou sociais da comunidade, ainda que certas metas sejam negativas, por implicarem na proteção de determinada característica da comunidade contra uma mudança hostil. Nas palavras de Dworkin "os argumentos de princípio se propõem a estabelecer um direito individual; os argumentos políticos se propõem a estabelecer um objetivo coletivo. Os princípios são proposições que descrevem direitos; as políticas são proposições que descrevem objetivos". ${ }^{35}$

A definição de políticas públicas como fenômeno relacionado ao universo jurídico é corolário do movimento pós-positivista de integração do direito com a política, moral, ética, sociologia, economia, etc. Desta maneira, as políticas públicas possuem natureza jurídica mista, haja vista o fato de ser concebida como um fenômeno político e jurídico, concomitantemente. Em sentindo distinto, argumenta Bucci, que "as políticas públicas não são, portanto, categoria definida e instituída pelo direito, mas arranjos complexos típicos da atividade político-administrativa, que a ciência do direito deve estar apta a descrever, compreender e analisar, de modo a integrar à atividade política os valores e métodos próprios do universo jurídico". 36

Para concluir a ideia sobre políticas públicas no sentido relacionado ao universo jurídico, só é possível se estiver associada a um arsenal de garantias definidas pelo Ordenamento Jurídico. Diante desse contexto, relata-se também a importância quando todos os princípios e objetivos constitucionais são juridicamente vinculantes para todos os órgãos do Estado. Desta maneira, é provável uma compreensão das políticas públicas como categoria jurídica a fim de concretizar os direitos fundamentais sociais definidos constitucionalmente.

35 DWORKIN, Ronald. Levando os direitos a sério. Tradução e notas Nelson Boeira. São Paulo: Martins Fontes, 2002, p. 134.

${ }^{36}$ BUCCI, Maria Paula Dallari. O conceito de política pública em direito. In Políticas Públicas: reflexões sobre o conceito jurídico. Maria Paula Dallari Bucci (organizadora). São Paulo: Saraiva, 2006, p. 31. 


\subsection{PROUNI - POLÍTICA PÚBLICA DA EDUCAÇÃO SUPERIOR VIGENTE NO BRASIL}

O ProUni é parte principal no estudo, sendo dimensionado para a situação do acesso à educação superior, visto como uma política de inclusão social. Assim, apresenta-se como uma medida inovadora do governo federal que tem como objetivo a concessão de vagas para estudantes de baixa renda em instituições privadas de ensino superior. Este programa foi implementado por meio de políticas públicas, regulamentado pela Medida Provisória n. 213/2004, e institucionalizado pela Lei n. 11.096, de 13 de janeiro de 2005. Nesse sentido, essa política pública que criou o ProUni, possibilitando meios para a equidade como igualdade de oportunidades ao acesso na educação superior.

Sob as considerações da professora Maria Rita Aprile $^{37}$, o ProUni é considerado sob diferentes perspectivas - como política focalizada e compensatória, privatista e como ação afirmativa - sendo uma política pública de âmbito nacional para garantir e oportunizar o acesso à educação superior de uma classe menos favorecida da sociedade. Assim assegurando a inclusão de grupos que antes não tinham perspectivas de estudo, com isso buscando cumprir as metas que foram propostas no PNE da Lei n. 10.172/2001.

O ProUni, sendo inserido na dimensão das políticas inclusiva compensatórias, terá como meta retificar as brechas deixadas pelas insuficiências das políticas universalistas. Para melhor compreender tal entendimento Cury, sinaliza que, para isso, "busca-se equilibrar uma situação sempre que a balança tende a favorecer grupos hegemônicos no acesso aos bens sociais, conjugando, ao mesmo tempo, os princípios de igualdade com o da equidade, compreendida como a melhor escolaridade. Buscam também atender à dimensão de uma inserção profissional mais qualificada mediante uma base maior de inteligência, visando ao desenvolvimento científico e tecnológico do país". 38

37 APRILE, Maria Rita; BARONE, Rosa Elisa Mirra. Educação superior: políticas públicas para inclusão social. Revista @ mbienteeducação, São Paulo, v. 2, n.1, p. 39-55, jan./jul. 2009.

38 CURY, Carlos Roberto Jamil. Políticas inclusivas e compensatórias na educação básica. Cadernos de Pesquisa. (35), n. 124, SP, FCC, jan. / abril, 2005, p. 11-32. 
Com vistas à redistribuição de oportunidades de vagas na educação superior, para as camadas populares, o acesso a esse nível da educação é definido pela CR como bem público e pela LDB/96, como direito social do cidadão. Para afirmar essa visão imposta pela política pública que institui o ProUni, vale lembrar os ensinamentos exposto pelo jurista Canotilho, quando se fala em oportunidades às camadas populares:

Uma opção realista pelos pobres assentará em uma perspectiva inclusiva e dialógica, não devendo eliminar nenhuma camada de excluídos. Em segundo lugar, uma opção pelos pobres leva a sério todas as pessoas, tendo em conta a situação concreta. Por palavras muito em voga na sociologia americana, o direito deve ter aberturas dialógicas para os rostos, os corpos, as almas, dos que enfrentam as dificuldades da dor, da pobreza, do isolamento, da opressão, da ignorância (pobres sem meios de subsistência, doentes, perseguidos, discriminados, velhos, humilhados). ${ }^{39}$

No entanto, quando o debate gira em torno do acesso das camadas populares à educação superior, há questões negativas a acerca do ProUni. Para isso Nadir Zago, discute nesse sentido sobre as problemáticas que circundam a presença das camadas populares, sem condições de permanência e de escolha sobre a sua vida acadêmica, como o fenômeno da "exclusão dos excluídos". 40

Sendo o ProUni uma política pública de inclusão social para a educação superior, a fim de que haja efetividade no que diz respeito a serviços sociais fundamentais, a garantia de acesso a esse nível educacional deve partirde uma equitativa de igualdade de oportunidades a todos os cidadãos que desejarem usufruir dessa política pública.

${ }^{39}$ CAnotilho, J. J. Gomes. O Direito dos Pobres no Activismo Judiciário. In: CANOTILHO, J. J. Gomes; CORREIA, Marcus Orione Gonçalves; CORREIA, Érica Paula Barcha. Direitos Fundamentais Sociais. 1 ed. São Paulo: Saraiva, 2010, p. 33.

${ }^{40}$ ZAGO, Nadir. Do acesso à permanência no Ensino Superior: percursos de estudantes universitários de camadas populares. Revista Brasileira de Educação. v. $11 \mathrm{n}$. 32maio/ago. 2006. 


\section{APRESENTAÇÃO DOS RESULTADOS}

Os resultados foram apresentados em duas partes distintas. $\mathrm{Na}$ primeira demonstraram-se os dados relativos às características dos participantes quanto aos seus aspectos socioeconômicos e demográficos, tais como: gênero, idade, estado civil, situação econômica na época em que ingressou e teve acesso a bolsa do ProUni, situação profissional se já estava engajado no mercado de trabalho quando ingressou na educação superior, nível de escolaridade dos pais e informações familiares relevantes.

A segunda parte demonstrou-se por meio dos discursos extraídos a partir das entrevistas, dos temas explorados, seus agrupamentos, com as respectivas ideias centrais e ideias que serão agrupadas para formar o DSC unificado relacionado ao tema em questão.

\subsection{ANÁLISES DOS DSC}

As análises dos conteúdos das entrevistas foram subdivido em duas partes, sendo a primeira direcionada aos atores sociais que estão fazendo jus ao benefício da bolsa do ProUni, estes foram nomeados de ativos; já os atores sociais da segunda parte, são aqueles que já tiveram o benefício da bolsa ProUni e já se encontram no mercado de trabalho, engajados na profissão, estes foram nomeados de egressos.

Para melhor compreensão do método utilizado seguem as questões, as tabelas com as respectivas categorias, gráficos com percentuais de cada categoria e os discursos oriundos destas.

\section{ATIVOS}

\section{1 - Se um colega lhe perguntasse; o que significa para vo- cê ser estudante universitário? 0 que você lhe responde- ria?}

\section{Resultados quantitativos}




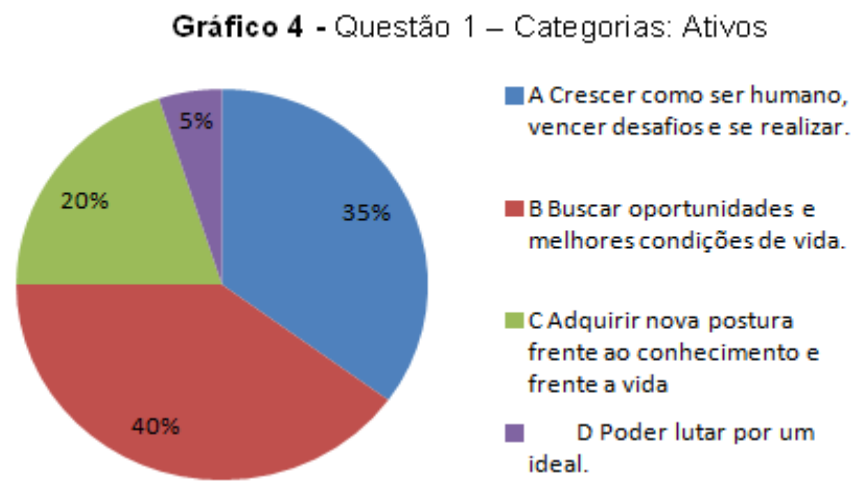

\section{Resultados qualitativos}

\section{A- Crescer como ser humano, vencer desafios e se realizar.}

Ser estudante universitário significa crescer como pessoa, aprender a ser adulto, conviver com pessoas totalmente desconhecidas e encontrar nelas o apoio que se precisa quando se está longe da sua família. Sou nascida em uma família muito pobre, onde o pai abandonou quatro filhos e a mãe teve que arcar com tudo sozinha. Tudo era medido e regulado. Buscar o sonho acabou sendo uma forma de tirar esse biótipo de que somente rico faz curso superior. Sempre fui dedicada e quando coloco algo na cabeça me esforço mais ainda para conseguir. Já fui aprovada 4 vezes pelo Prouni e hoje curso o que sempre desejei e que me vejo trabalhando num futuro próximo. Como diz minha família e amigos: quem foi que disse que o raio não cai no mesmo lugar? Eu sou prova disto. Claro que não é fácil tudo isso; é acima de tudo encarar você do jeito que é e vencer a si mesmo, pois estudar é um desafio diário que requer a todo o momento controle sobre si, dedicação e foco onde se quer chegar. É mais do que um sonho, é uma meta, um objetivo que eu almejava e que com muito esforço foi alcançado. Em suma é uma conquista, um estado de realização, de busca pelo conhecimento, de aprender limitações e lidar com elas. Mais do que um diploma, cursar e concluir uma universidade é um sonho que se realiza.

\section{B -Buscar oportunidades e melhores condições de vida.}

Ser universitário é ser alguém que busca uma condição de vida melhor pra si e pra familia; é estar se graduando a fim de ingressar no mercado de trabalho como um profissional. Quem cursa uma universidade tem mais chances de ascensão, melhorando significativamente seu currículo.

Venho de uma familia onde pai e mãe fizeram apenas o primário. A oportunidade de ingressar na universidade abre portas para sua inserção no mercado de trabalho e ao dizer-se universitário você passa a ser visto com outros olhos.Significa um futuro melhor, a concretização de uma realização pessoal, um esforço anterior que valeu a pena, e também, fazer parte de um grupo composto por apenas $14 \%$ dos jovens no Brasil, o que te coloca em uma posição privilegiada, pois durante muito tempo esse foi um privilégio que só as classes 
mais altas podiam ter. Muitas vezes o que você precisa é uma oportunidade para mostrar que pode ser tão bom aluno e/ou tão bom profissional quanto aquele que sempre teve esse acesso garantido. Alguém que busca conhecimento, que corre atrás das oportunidades que Ihes são oferecidas e aproveita cada uma delas, tendo mais responsabilidade do que um estudante de ensino médio. Não tem mais a cobrança de professores, você tem que correr atrás do que quer, tem que se esforçar muito e sacrificar muitas coisas de que gosta. Mas todo esforço vale a pena, pois cada sacrifício agora trará grandes coisas em seu futuro.Significa também ter a oportunidade de exercer uma atividade laboral menos extenuante e melhor remunerada. Além disso, o fato de conviver com diversas pessoas, te traz novos contatos que podem ser úteis no futuro. Além disso, é uma oportunidade de ascensão social, pois significa estabilidade econômica e social futura, permitindo conhecer as grandes possibilidades que o mercado oferece e com isso poder realizar-se.

\section{B- Adquirir nova postura frente ao conhecimento e frente a vida}

Ser um universitário é bem diferente da imagem que temos no ensino médio. $O$ ensino público não prepara o estudante para a vida em si, deixa-o acostumado com a facilidade das coisas, mas em uma universidade quem tem de buscar as oportunidades é o próprio aluno. Limitar-se à sala de aula, como fazemos no ensino médio não ajuda, quando estamos no ensino superior, temos de pesquisar por nós mesmos, estudar por si só e acima de tudo ter uma responsabilidade a que não somos acostumados.

o povo brasileiro é acostumado desde cedo a ter as coisas sem muito esforço, mas quando a vida real chega, a situação muda, principalmente se você não nasce em um berço de ouro, é nesse ponto que muitas pessoas desistem dos sonhos e se tornam apáticas. Por estes e outros motivos a cultura universitária deve ser trabalhada desde cedo Se você quer ser um estudante universitário tem que ter estas coisas em mente e começar desde já a trabalhá-las ou quando chegar realmente a universidade terá sérios problemas. É uma responsabilidade grande, pois é a base para a formação profissional, muitos costumes precisam ser deixados de lado e o empenho e a perseverança precisam ser um lema. Passamos noites em claro e constantemente somos cobrados por familiares e amigos pela nossa ausência. Criamos o habito de ler mais do que antes, estudar mais do antes e consequentemente nos tornamos seres melhores e mais preparados para o mercado de trabalho e para a vida. Temos que criar as próprias oportunidades, correr atrás do futuro, ampliar o conhecimento e a ter a possibilidade de refletir sobre temas variados da atualidade com um olhar cientifico a cerca desta realidade. Desenvolver pesquisas que contribuam para 0 fortalecimento da profissão e para novas práticas profissionais.

\section{C- Poder lutar por um ideal.}

Significa acima de tudo a oportunidade de poder lutar por um país melhor, por um sistema de saúde mais eficiente e verdadeiramente universal, considerando-se que o meu curso me permite ter uma dimensão bastante exata do que é e como funciona o SUS.

\section{2 - Diga para mim, em que o ProUni tem contribuído para esses significados que você acaba de comentar comigo.}

\section{Resultados quantitativos}


Gráfico 5 - Questão 2 - Categorias: Ativos

A Contribuição para realização de um sonho
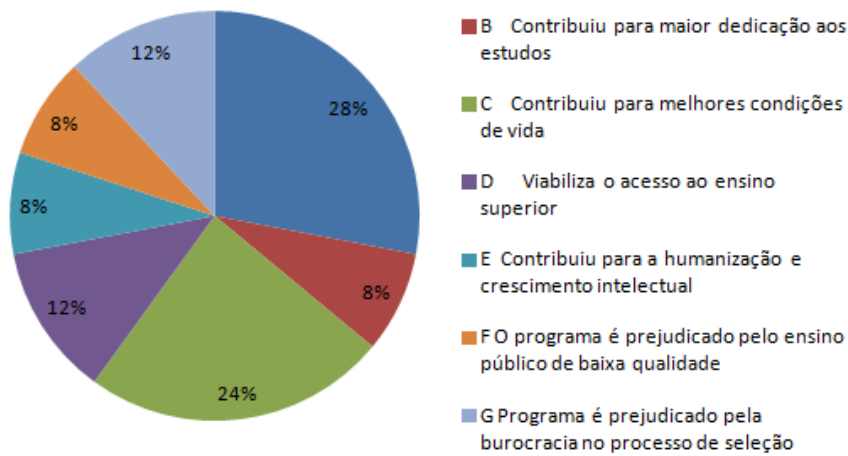

\section{Resultados qualitativos}

\section{A - Contribuição para realização de um sonho}

O ProUni tem contribuido de maneira significativa no objetivo de cursar Medicina e atingir todos os objetivos acima citados....Antes do ingresso no ProUni em 2011, eu já cursava Farmácia na Universidade Federal de Alfenas e estava de certa forma integrado ao Sistema Único de Saúde, em estágios e atividades de extensão. Mas foi com a mudança e curso que eu pude realmente trilhar o caminho outrora planejado-sonhado. Bom, foi a bolsa do ProUni que possibilitou esta conquista pessoal, em ser o orgulho dos meus pais ao receber um diploma universitário. Então, o benefício é fator determinante que tornou possível essa realidade: tenho dedicação total à minha formação acadêmica e encaro a realidade da melhor maneira possível porque estou fazendo o que mais amo, estudo Medicina. Graças a Deus passei pelo ProUni, se não fosse a bolsa permanência somada à estrutura e aos livros disponíveis na biblioteca, com certeza, tudo seria muito mais difícil e até mesmo, talvez não estivesse, neste momento, realizando meu sonho. O que possibilitará a ajudar minha familia.

\section{B - Contribuiu para maior dedicação aos estudos}

O estudante do ProUni também tem que se dedicar mais para não perder sua bolsa, e esse tempo a mais estudando faz toda diferença no aprendizado. Após a bolsa do ProUni houve a possibilidade de trabalhar somente meio período e dedicar aos estágios, programas como iniciação científica, cursos online na área entre outros.

\section{C - Contribuiu para melhores condições de vida}

O Prouni foi essencialna minha vida é uma oportunidade de conquistar os sonhos e conseguir abrir as portas para o mercado de trabalho e universitário, num País onde a desigual- 
dade social é escandalosa, nós que não viemos da Classe favorecida se não existissem estes programas seria impossível cursar uma faculdade. Poderiam questionar em relação às universidades públicas, mas acredito que elas também foram feitas àquela classe favorecida, pois a maioria dos estudantes das mesmas são aqueles que estudaram uma vida inteira em colégio particular. Isso por dois motivos: somente eles podiam pagar as altas mensalidades de uma instituição privada, ou, como tiveram um ensino de melhor qualidade em escolas particulares, tinham mais chances de passar no processo seletivo de uma universidade pública. Ademais para se manter numa universidade não é barato e meus pais não teriam condições se eu não trabalhasse para ajudá-los. Claro que depois do SISU a história mudou um pouco, mas ainda deixa a desejar. Hoje, se não fosse pelo programa eu não estaria cursando uma universidade, pois o valor das mensalidades é muito mais do que meu salário, sem contar nas despesas extras, como condução, livros e Xerox. O programa tem contribuído com toda certeza positivamente, pois sem essa bolsa de estudos dificilmente estaria em uma sala de universidade. Sem essa bolsa, eu não teria condições de estudar em 2011, fui selecionada pelo programa para o curso de GPI e como desisti do curso, me inscrevi novamente em 2012 e consegui para o curso de matemática. É um programa que funciona sim e que tem beneficiado muitos em adquirir o máximo de conhecimento possível. O ProUni veio para dar oportunidades para pessoas de baixa renda, que estudaram em

escolas públicas. E um ótimo programa e eu sou testemunha disso. Ainda possibilitou o meu primeiro emprego formal, já na área em que estudo, tenho boas perspectivas de crescimento no meu atual emprego, contribui para que pudesse me tornar uma universitária.

\section{D - Viabiliza o acesso ao ensino superior}

O ProUni contribuiu para melhoras na minha vida sim. Pois, motiva os alunos a buscar o conhecimento e se esforçar sem depender de alguém, torna o estudante mais dedicado e decidido além de proporcionar a pessoas de baixa renda uma oportunidade de melhorar de vida, culturalmente e financeiramente. Em si é como uma recompensa pelo penoso esforço que passamos para consegui-lo. Como já foi dito, somente as classes mais altas tinham acesso a universidade. Além disso, o programa ajuda pessoas que não teriam condições de pagar a faculdade a conquistar o sonho de ter um curso superior.

\section{E - Contribuiu para a humanização e crescimento intelectual}

Este programa equipara todos os alunos não fazendo distinção de classe econômica $e$ contraria a afirmação de senso comum de que aluno de escola pública não tem preparo para a universidade, em nenhum momento durante a graduação me senti lesada por isso. Por outro lado, capacita-nos para orientarmos também outros cidadãos no seu exercício de cidadania. O mundo acadêmico é responsável por desenvolver a Ciência nas mais variadas áreas do conhecimento, promovendo o gosto pela profissão e estudos a respeito de novas técnicas como recursos de trabalho. Sem o ProUni muitos profissionais não estariam hoje onde estão, com certeza isso não melhora apenas a pessoa e sim o país ao todo que ganha capital humano e na valorização dele próprio no exterior. Além disso, possibilita um crescimento pessoal e intelectual, mostra uma gama de possibilidades para execução da profissão e acima de tudo, nos prepara para sermos cidadãos orientados, em pleno poder de exercer o dever e requerer o direto. 


\section{F - O programa é prejudicado pelo ensino público de baixa qualidade}

O ensino nas escolas públicas não dá base para a realização do Enem. As provas são extensas, e confundem pela quantidade e estresse. Demorei mais de quatro anos para perder 0 medo de realizar o Enem, uma vez que acreditava não ser capaz de conseguir me sair bem na prova. Pois, mesmo que eu consiga absorver bem os conteúdos ministrados, o ensino na rede pública é deficiente e quando fiz o Enem pela primeira vez, para conhecimento, consegui a pontuação de 660 pts, quando saiu o resultado duas notas não saíram pode ter ocorrido falha no sistema, tentei pela segunda vez, aí sim consegui a vaga. Mesmo com a dificuldade para conseguir a bolsa, ficando em $20^{\circ}$ lugar, me inscrevi na lista de espera e por várias razões (documentações) de outros candidatos, consegui chegar até a vaga.

\section{G- Programa é prejudicado pela burocracia no processo de seleção}

Sou aluna bolsista do ProUni e só estou no curso superior por conta do mesmo e se encontro alguém falando sobre o assunto eu sempre digo: "vá faça o Enem". As escolas públicas não preparam devidamente o aluno para as provas do Enem, que é meio para conseguir a bolsa, o ensino público não trás uma base mínima para que o aluno/candidato realize uma prova eficiente no Enem deixando, inicialmente, o candidato com medo de realizar o Enem e posteriormente, se sentindo incapaz de conquistar seus sonhos. Quando o candidato consegui uma pontuação para conquistar o ProUni, a burocracia dificulta seu ingresso para a universidade. Para selecionar a documentação foi necessário muito empenho, viagens, provar o obvio. Chegando ao ponto de provar que minha mãe leva uma vida totalmente distinta da minha e não tem condições de me ajudar e provar com a certidão de óbito do meu pai, que abandonou a família em 1983, sem nunca auxiliar em nada, foram tantas documentações reconhecidas em cartório, que um determinado momento, achei não ser capaz de conseguir, como ocorreu com os candidatos que me antecederam. $O$ valor da renda média e a mais comprometedora, fazendo com que uma diferença de $(R \$ 1,00)$ um mísero real desqualifique o candidato.

Assim iniciando um processo maior e muito burocrático de recolher os documentos necessários para a entrevista, acredito que deveria ter um modo menos burocrático para facilitar 0 processo. Por outro lado, há noticias de fraude em documentos apresentados para o processo de ingresso na universidade pelo ProUni.

Por fim ingressei na universidade mesmo com as dificuldades apresentadas.

\section{EGRESSOS}

1. Se um colega lhe perguntasse: como você se encontra na vida profissional. 0 que você lhe diria?

\section{Resultados quantitativos}




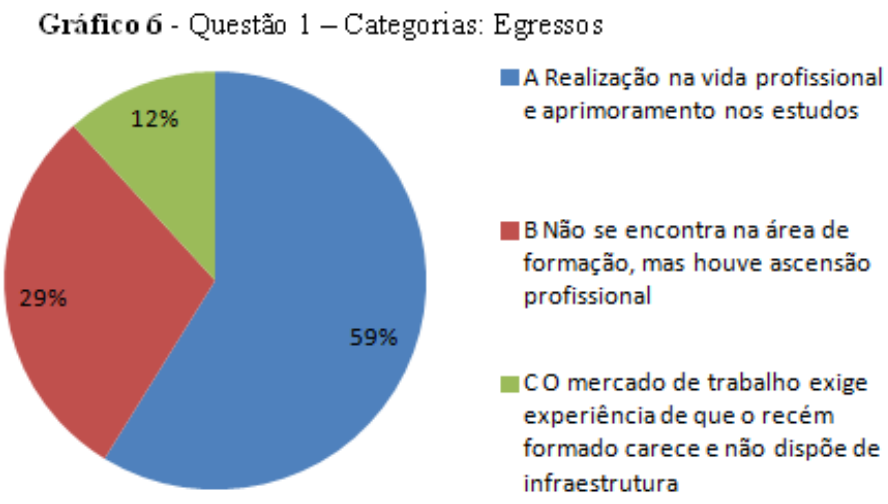

\section{Resultados qualitativos}

\section{A - Realização na vida profissional e aprimoramento nos estudos}

Encontro-me feliz com os rendimentos e experiências adquiridas, satisfeito profissionalmente: graças ao auxílio do ProUni, o ensino superior deu base para o crescimento profissional. No entanto, os médicos brasileiros vêm sofrendo críticas governamentais, e isso causa frustração. Mesmo satisfeito com a vida profissional, continuo estudando. Ainda participo de trabalho social voluntário, estou terminando um pós graduação e já pretendo ingressar em outra para obter mais aprimoramento e experiências.

\section{B - Não se encontra na área de formação, mas houve ascensão profissional}

Sou o único com curso superior na família, pois meus pais não tinham condições de custear uma faculdade. Ainda não estou porém na área de formação do curso superior, e nem desenvolvo os conhecimentos adquiridos. Mas estou satisfeita, pois trabalho por conta própria e o mercado de trabalho oferece grandes oportunidades na área; estou tranquila e preparada: após o ensino superior consegui uma melhor colocação no mercado e ascensão na vida profissional.

\section{C - O mercado de trabalho exige experiência de que o recém formado carece e não dispõe de infraestrutura}

Estou parcialmente, satisfeito, pois os profissionais recém formados não têm a experiência que o mercado exige. E por outro lado, os profissionais da saúde têm encontrado condições precárias, sem o mínimo de estrutura física para que o trabalho seja desenvolvido em prol da sociedade e de um país melhor.

\section{Diga ainda para esse colega em que o ProUni contribuiu para sua atuação profissional.}




\section{Resultados quantitativos}

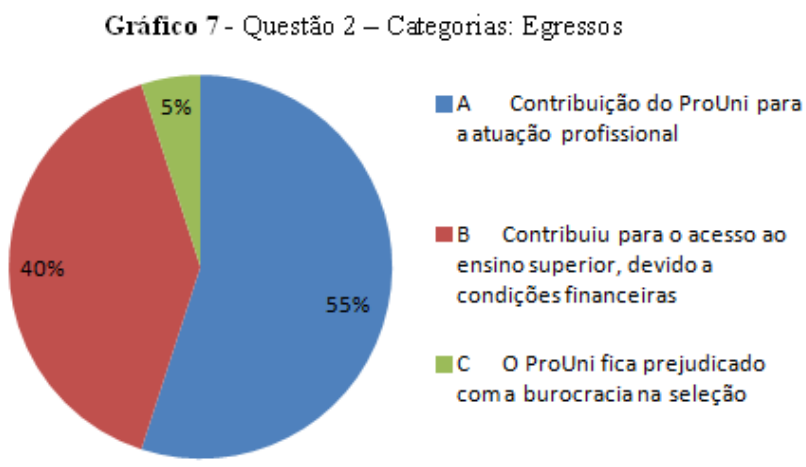

\section{Resultados qualitativos}

\section{A - Contribuiu para o crescimento e atuação profissional}

O Programa foi muito importante, uma ferramenta de bolsas do governo que me tirou do ambiente daquele jovem sem oportunidades que eu me encontrava. Se não fosse o ProUni teria perdido as expectativas de crescimento profissional. O surgimento desse programa veio como um fator determinante para o ingresso no ensino superior foi essencial para realização de um sonho de ser médica, permitindo maiores oportunidades, dedicação aos estudos, melhores condições e colocação no mercado de trabalho, renda e experiência. Sendo um grande diferencial no currículo e fundamental na vida, possibilitando reconhecimento na atuação profissional. Na verdade, os alunos do ProUni são dedicados com os estudos, e isso contribui significativamente para a carreira profissional.

\section{B - Contribuiu para o acesso ao ensino superior, devido a condições financeiras}

O Prouni foi um grande facilitador, pois não tinha condições financeiras de custear a faculdade. Não tive condições de permanecer no ensino superior e tive que trancar a matricula e retornar após ter conseguido a bolsa. As condições financeiras não permitiam o ingresso no ensino superior, por isso o ProUni foi importante. Assim, contribuiu para a minha formação, permitiu a oportunidade de fazer um curso superior, abrir portas para o estudo $e$ trabalho, possibilitando melhores condições financeiras, maior dedicação e melhores notas. Dessa maneira, encontro-me satisfeito profissionalmente, sem o programa não teria condições de ter o salário e profissão que tenho. Se não fosse o programa estaria insatisfeito profissionalmente. Por isso, agradeço pelo programa que me possibilitou melhores condições de vida.

\section{C - O ProUni fica prejudicado com a burocracia na seleção}


A burocracia na seleção retarda ou atrapalha o ingresso no ensino superior, mesmo com uma fiscalização e avaliação rígida, há indícios de falsificação de documentos para conseguir a bolsa.

\section{$4 \quad$ DISCUSSÃO E ANÁLISE}

Neste capítulo será exposta a discussão dos resultados, ressaltase que a análise desenvolve-se mediante os discursos dos alunos do ProUni, tendo como foco o acesso à educação superior, junto a Univás. Esta busca de informações a campo teve como intuito de contextualizar a argumentação relacionada às políticas públicas que articulam o efetivo exercício da igualdade de oportunidade ao acesso à educação superior.

Os discursos foram organizados a partir do conteúdo extraído das entrevistas. A entrevista semiestruturada fez-se por meio de quatro questões, que buscaram delimitar a compreensão, o conhecimento, valores e o entendimento sobre a problemática do acesso ao ensino superior para estudantes de baixa renda e oriundos de escolas públicas em instituições de ensino superior (IES) privadas - no entanto, a pesquisa teve como foco a política pública, que deu origem a Lei n. 11.096/05 - ProUni, que possibilita o acesso da população de baixa renda ao ensino superior.

A partir do conteúdo das entrevistas percebeu que a política pública do ProUni, partindo dos pressupostos extraídos do método, possibilitouvisualizar que está havendo uma tímida efetivação do direito social à educação, com o devido acréscimo de uma "essência" ao direito fundamental à educação assegurado no artigo $6^{\circ}$ da $\mathrm{CR}$, com vistas ao alcance de uma justiça social, permeando a efetivação do direito ao exercício da igualdade. Isto por meio de implementação e execução da política pública, que surge como um plusnormativo, vislumbrando um direito que estende, ou seja, que expande àquele direito já previsto e assegurado pela Constituição da República e LDB.

Para delimitar o exposto acima, faz-se necessário analisar o seguinte tripé acompanhado de suas atribuições, visando à efetivação do direito social à educação, porém com um plus normativo que contemple o ensino superior, possibilitando transformações da democracia sob a forma de "promessas não cumpridas" ou de adaptação natural dos princípios que estão abstratamente inclusos à realidade social.

Para melhor visualização da tríade que contém nesta pesquisa, representada pela demanda social em razão do acesso ao ensino superior; 
pela formulação de uma política pública que implementada pelo governo federal sob o direito ao acesso ao ensino superior e para angariar tal política pública e possibilitar o acesso a população de baixa renda, é necessária uma instituição privada que faça a adesão à política pública. Assim, é necessário expor três pontos principais, para que essa tríade aconteça, conforme segue.

Para melhor idealização de que está havendo uma efetivação do direito social à educação, com ênfase no acesso à educação superior por meio da política pública, instituída com essa finalidade, é possível demonstrar um desmembramento das ações da política pública que se faz em cinco passos, mediante contextualização dos discursos.

O primeiro passo se efetivou com a ação do governo federal que instituiu a política pública, por meio da Lei $n^{\circ}$. 11.096/2005, que possibilita o acesso da população de baixa renda, ao ensino superior, assim oportunizando aos cidadãos o direito ao efetivo exercício da igualdade, projetando-nos melhores condições de vida digna. Neste momento ocorreu a percepção de que há uma correlação dos discursos oriundos da segunda questão que se relaciona ao fato do benefício do ProUni, em que o mesmo contribuiu para a atuação profissional dos participantes.

O segundo passo se dá pela execução, ou seja, pelo funcionamento e realização da política pública, quando o cidadão de baixa renda busca o benefício e ingressa no ensino superior e também pela ação da instituição privada que adere à política pública e cumpre o seu papel social no momento em que firma uma parceria pública-privada, assim atingindo a sua finalidade da política pública. Neste momento em que se dá a parceria pública-privada, relaciona-se a ideia do discurso exposta na terceira categoria que diz respeito ao fato de que "o ProUni fica prejudicado com a burocracia na seleção". Para dimensionar a ideia advinda desta categoria reproduz-se o discurso, quando explicitou que "a burocracia na seleção retarda ou atrapalha o ingresso no ensino superior, mesmo com uma fiscalização e avaliação rígida, há indícios de falsificação de documentos para conseguir a bolsa". Este discurso diante da sistemática da questão não apresentou significância para o estudo, uma vez que desviou o foco da entrevista e não relatou nada no que se refere ao benefício oriundo do programa com contribuição profissional.

O terceiro passo é identificado pela concretização do objetivo da política pública, isto é visível quando o cidadão de baixa renda, em razão do benefício oriundo da política pública, que permitiu o acesso ao 
ensino superior, já se encontra no mercado de trabalho, satisfeito profissionalmente e a posição social é outra, sendo diferente daquela que o fez ser beneficiário de uma política pública, que tinha por objeto atingir a classe baixa. Esse cidadão não se encaixa mais naquela posição social. Com o benefício foi possível mudar de classe social e econômica, reduzir àquela gama de desigualdade social que era parte de si e ainda oferecer à sociedade um profissional qualificado.

O quarto passo foi verificado nos resultados da análise das entrevistas, pelo resultado positivo que gerou, uma vez que, o beneficiado da política pública indicou a realização pessoal do indivíduo, quando este tem oportunidade da livre escolha da atividade profissional, sem ter o empecilho de fator econômico que antes impedia. Verificou-se também que o profissional que está inserido na sociedade em razão de tal benefício, teve um crescimento, uma ascensão na atuação profissional pela oportunidade de acesso ao ensino superior e também uma melhor qualidade e condições de vida.

O quinto passo verificou-se no momento em que foi possibilitado, "vez a voz" (discurso) ao cidadão referente ao assunto sobre a política pública de acesso ao ensino superior, isso só foi possível pelo método do DSC, utilizado na pesquisa. Está dimensão do estudo corrobora com o objetivo principal que afere ao cidadão conhecer os significados de ser estudante universitário do ProUni, enquanto política que articular o exercício da igualdade. Dessa maneira, com intuito de associar a dimensão do método e a perspectiva jurídica do estudo realizou-se a discussão do mesmo partindo das bases teóricas da política pública e dos resultados demonstrados neste estudo, em que se demonstra que ocorreu a efetividade do direito a educação, ou seja, aconteceu o acesso ao ensino superior previsto pela Lei n. 11.096/05.

\section{CONSIDERAÇÕES FINAIS}

Ao longo do presente trabalho, buscou-se analisar a política pública que assegura o direito ao acesso ao ensino superior, mediante o objetivo de conhecer os significados de ser estudantes universitários do ProUni, da Univás, como política pública, que articula o efetivo exercício da igualdade, dimensão capaz de possibilitar um alcance da justiça social. 
Por outro lado, a implementação da política pública teve como escopo elevar os princípios gerais de toda a ordem jurídica, que buscou delinear pretensões para um regime de democracia substancial, ao determinarem a realização de fins de direitos sociais, por meio da atuação de programas na ordem econômica, com vistas a assegurar a todos, a oferta de oportunidades, por meio do acesso ao ensino superior e a livre escolha da profissão, sendo possível a busca de uma melhor qualidade de vida, conforme os preceitos da justiça social, que pugnam por um desenvolvimento do cidadão.

A dimensão metodológica do estudo resultou num entendimento de que a amplitude do método utilizado permitiu uma visão da realidade social, principalmente, do grupo focal, que a partir de suas considerações mensuradas nos discursos, possibilitou uma articulação para as práticas sociais do Direito. Isto se deu quando ocorreu o fato de o cidadão neutro numa sociedade de ampla desigualdade social, se ver como beneficiário de uma política pública, que projeta os fundamentos do Estado Democrático numa concepção invisível, desenvolvida mediante a soberania que adveio do Estado ao instituir a política pública, e ainda a soberania que teve a população carente em exercer a vontade geral, que demandou uma política social de acesso ao ensino superior e enfatizou a relação entre o Estado e a necessidade de legitimação do poder político para a instituição de uma lei.

Outra concepção que se desenvolveu para a compreensão acima foi explicitada pela cidadania que teve presença marcante no estudo, partindo do fato em que o indivíduo tem a possibilidade de articular seus ideais de formação profissional, realização daquilo que antes era apenas um sonho em ingressar no ensino superior, ter a oportunidade de ascensão social e econômica, participação ativa para o exercício da igualdade de direitos.

Outro princípio que reluz no presente estudo, e integra o Estado Democrático de Direito são os valores sociais do trabalho e a livre iniciativa. Isso teve grande visibilidade com a aplicação do método, quando os beneficiários egressos da política pública trouxeram em seus relatos que haviam superado as barreiras sociais, onde não podem ser observadas somente numa lógica de conquistas individuais, e sim numa perspectiva coletiva inserida em um contexto favorável de desenvolvimento econômico e social atualmente no Brasil. Para os egressos do ProUni, o acesso à universidade significa uma nova perspectiva de ampliar o conhecimento, as relações sociais, as possibilidades de formação profissional, acesso 
ao mercado de trabalho e mobilidade social. Isto permite que o indivíduo que antes tinha um direito negado até então, em razão de fatores econômicos, atualmente este direito está conquistado e permite-se a igualdade na escolha profissional.

Considerando as exposições acima, verificou-se o caráter social da política pública do ProUni, que representou para o grupo estudado uma possibilidade singular de acesso à educação superior e oportunidade de competições iguais para o ingresso no mercado de trabalho. Ainda o programa possibilita perspectivas de se ansiar o desenvolvimento social, a redução de desigualdades que deve enfrentar o desafio de combinar democracia com eficiência econômica e justiça social, além de pretender o alcance de um tratamento igualitário a todos os cidadãos.

Todos os aspectos suscitados no levantamento dos resultados e na discussão foram explícitos quanto aos méritos positivos que elencam o programa. Mas de outro lado, percebeu-se que há uma grande lacuna na educação do país, devido ao fato de que a política pública do ProUni trata-se de investimento para o acesso ao ensino superior, enquanto o Estado oculta uma evidência fragilizada que é histórica na qualidade do ensino no nível básico. Isso projeta, na realidade, uma redução potencial da demanda, que não demonstra um atendimento satisfatório, devido ao mau desempenho na educação básica.

Em suma, pode considerar que a política pública vem apresentando uma gradual realização do Direito, no que tange à capacidade de produzir efeitos, ou seja, no tocante à adequação da norma à realidade. Dessa maneira partindo do entendimento de que a CR se realiza num contexto cultural, é possível vislumbrar uma abertura constitucional para novas interpretações, porém assegurando ao cidadão o conhecimento de que a Constituição de seu país é fruto não só da intelectualidade, mas também de reivindicações que buscam formar uma sociedade "livre, justa e solidária". Com isso permite-se que o cidadão consciente tenha com a amplitude do texto constitucional, um mecanismo auxiliar na interpretação e frequência dessa lógica, possibilitando que se faça uma abertura do conteúdo constitucional, que possa nortear a CR aberta para a realidade social e, portanto, democrática.

\section{REFERÊNCIAS}


AGUIAR, Eduardo Henrique de Almeida. Jurisdicionalização de Políticas Públicas. Ed. Rio de Janeiro: Livre Expressão, 2010. p. 18.

ALEXY, Robert.Teoria dos Direitos Fundamentais. Tradução de Virgilio Afonso da Silva. São Paulo: Malheiros Ed., 2008. p. 437.

APRILE, Maria Rita; BARONE, Rosa Elisa Mirra. Educação superior: políticas públicas para inclusão social. Revista @ mbienteeducação, São Paulo, v. 2, n.1, p. 39-55, jan./jul. 2009.

BOBBIO, Norberto; NOGUEIRA, Marco Aurélio. O futuro da democracia: uma defesa das regras do jogo. Rio de Janeiro: Paz e Terra, 1997. p. 109.

BUCCI, Maria Paula Dallari. O conceito de política pública em direito. In: Políticas Públicas: reflexões sobre o conceito jurídico. Maria Paula Dallari Bucci (organizadora). São Paulo: Saraiva, 2006. p. 31.

BUFFA. Ester. Educação e cidadania: quem educa o cidadão?/Ester Buffa, Miguel Arroyo, Paolo Nosella. - 14. ed. São Paulo: Cortez, 2010.

CANOTILHO, José Joaquim Gomes. O Direito dos Pobres no Activismo Judiciário. In: CANOTILHO, J. J. Gomes; CORREIA, Marcus Orione Gonçalves; CORREIA, Érica Paula Barcha. Direitos Fundamentais Sociais. 1 ed. São Paulo: Saraiva, 2010.

COMPARATO, Fábio Konder. Ensaio sobre o juízo de constitucionalidade de políticas públicas. Revista dos Tribunais, n. 737, março, São Paulo, 1997. p. 17.

CUNHA, Edite da Penha; CUNHA, Eleonora Schettini M. Política públicas sociais. In: CARVALHO, Alysson [et al.] organizadores. Políticas Públicas. Belo Horizonte: Editora UFMG; Proex, 2002. p. 14-15.

CURY, Carlos Roberto Jamil. Políticas inclusivas e compensatórias na educação básica. Cadernos de Pesquisa, v. 35, n. 124, p. 11-32, 2005.

D'AVILA, Geruza Tavares. $O$ ensino superior como projeto profissional para "ser alguém": repercussões de um cursinho pré-vestibular popular na vida dos estudantes. Dissertação de Mestrado, Programa de Pós-Graduação em Psicologia, Universidade Federal de Santa Catarina, Florianópolis, SC. 2006.

DWORKIN, Ronald. Levando os direitos a sério. São Paulo: Martins Fontes, 2007. p. 142. 
FAZENDA, Ivani. Interdisciplinaridade: qual o sentido? São Paulo: Paulus (Questões Fundamentais da Educação). 2003. p. 43.

HEIDEMANN, Francisco G. SALM, José Francisco/organizadores. Políticas Públicas e desenvolvimento. Brasília: Editora Universidade de Brasileira, $2^{\mathrm{a}}$ edição, 2010. p. 28.

IHERING, Rudolf Von. A luta pelo direito. Trad. Pietro Nassetti. São Paulo: Martin Claret, 2003. p. 27.

KALlÁS FILHO, Elias. A Constituição Econômica de 1988: Fundamentos, funções e enunciados - síntese. In: Democracia e Constitucionalismo/Alexandre Gustavo Melo Franco Bahia [et al.]; coordenadores Eduardo Henrique Lopes Figueiredo [et al.]. - Rio de Janeiro: Elsevier, 2012. p. 135.

FRISCHEISEN, Luiza Cristina Fonseca. Políticas Públicas a responsabilidade do administrador e o ministério público. São Paulo: Ed. Max Limonand. 2000. p. 57.

MARQUES, Antonio Emílio Sendimet al. Pela Justiça na Educação/coordenação geral Afonso Armando Konzen. Brasília: MEC. FUNDESCOLA, 2000.

PORTO, Claudio; RÉGNIER, Karla.O Ensino Superior no Mundo e no Brasil -Condicionantes, Tendências e Cenários para o Horizonte 2003-2025: Uma Abordagem Exploratória. Dezembro, 2003. Disponível em: http://portal.mec.gov.br/sesu/arquivos/pdf/ensinosuperiormund obrasiltendenciascenarios2003-2025.pdf. Acesso em 29 de jan de 2014.

RANIERI, N.B.S. (2000). Educação superior, direito e Estado na Lei de Diretrizes e Bases (Lei n.. 9.394/96). São Paulo: EDUSP /Editora da Universidade de São Paulo.

Ribeiro, Luiz César de Queiroz e Orlando Alves dos Santos Junior. "Democracia e cidade: divisão social da cidade e cidadania na sociedade brasileira", Análise Social, volume XL (174), pp. 87109, 2005. p 88.

SCHWARTZMAN, Simon. Por uma nova política de educação superior para o Brasil. 2007. Disponível em: http://www.schwartzman.org.br/sitesimon/?page_id=595\&lang=ptbr. Acesso em 15 de mar. de 2014.

STRECK, Lênio Luiz. Jurisdição Constitucional e Hermenêutica: Perspectivas e Possibilidades de Concretização dos Direitos 
Fundamentais Sociais no Brasil. Novos Estudos Jurídicos, vol. 8, n. 2, maio/ago. 2003, p. 257-301.

Hermenêutica, Neoconstitucionalismo e "o Problema da Discricionariedade dos Juízes". Anima: Revista Eletrônica do Curso de Direito da OPET, ano I, n. 1. Curitiba, 2009. p. 6.

WEBER, Max. Economia e Sociedade. São Paulo: Imprensa Oficial do Estado de São Paulo, 1999.

ZAGO, Nadir. Do acesso à permanência no ensino superior: percursos de estudantes universitários de camadas populares. Revista Brasileira de Educação. São Paulo, v. 11, n. 32, p. 226-237, maio/ago. 2006. 
